\title{
A practical method for enumerating cysts of ciliates in natural marine sediments
}

\author{
Mutsuo Ichinomiya*, Miwa Nakamachi, Akira Taniguchi \\ School of Agricultural Science, Tohoku University, Sendai 981-8555, Japan
}

\begin{abstract}
In order to determine the abundance of intact cysts of planktonic ciliates in natural sediments, we developed a new practical method using autofluorescence of the fixative glutaraldehyde. After treatment with glutaraldehyde, the cyst walls fluoresced yellowish-green under blue excitation. The fluorescence was always clear in the intact cysts, while only part of the empty cysts was weakly fluorescent. This fluorescence made detection of the intact cysts easy among detrital materials, even for the cysts covered with detritus. It was also easy to distinguish the ciliate cysts morphologically from other organisms that also fluoresced in the treated sediments. This method was compared with the density gradient centrifugation technique, and the advantage of the former in frequent and routine investigations is discussed.
\end{abstract}

KEY WORDS: Enumeration - Cysts - Glutaraldehyde - Natural sediments - Planktonic ciliates · Density gradient centrifugation

\section{INTRODUCTION}

It is widely accepted that oligotrich ciliates play an important role as heterotrophic and/or mixotrophic components of the planktonic assemblage in freshwater and marine environments. Some of them form a resting cyst to survive unfavorable seasons (Reid \& John 1978, Paranjape 1980, Reid 1987, Kamiyama \& Anzai 1990, Kim \& Taniguchi 1995, 1997, Kamiyama 1996, Müller 1996, Müller \& Wünsch 1999, Kim et al. 2002, Müller et al. 2002). However, quantitative information about ciliate cysts in natural sediments is still limited because of the absence of a quick method for cyst enumeration. To determine the abundance of ciliate cysts routinely, we need to develop a practical method similar to that developed for a particular group of dinoflagellate cysts (Yamaguchi et al. 1995).

In this study, we show that the cysts of marine planktonic ciliates always turn a fluorescent yellowish-green color after glutaraldehyde fixation and propose that glutaraldehyde treatment is a simple and quick method to quantitatively determine the cyst populations of ciliates in natural sediments.

\section{MATERIALS AND METHODS}

A sediment sample was collected at a station in Onagawa Bay $\left(38^{\circ} 26.30^{\prime} \mathrm{N}, 141^{\circ} 27.70^{\prime} \mathrm{E}\right.$; $22 \mathrm{~m}$ depth) near the transition zone between the subarctic and subtropical area of the western North Pacific in February 2004. The top $2 \mathrm{~cm}$ of sediment was sliced off and stored at $5^{\circ} \mathrm{C}$ in the dark. Two $1 \mathrm{~g}$ (wet weight) aliquots of the sample were suspended in ca. $20 \mathrm{ml}$ of distilled water and sonicated for $30 \mathrm{~s} ; 20$ to $100 \mu \mathrm{m}$ fractions were retained on a sieve. Of the sieved fractions, one was diluted with $10 \mathrm{ml}$ of distilled water and used for direct enumeration of cysts without treatment (control). The other fraction was treated with glutaraldehyde before cyst enumeration as follows: $1 \mathrm{ml}$ of $25 \%$ glutaraldehyde (Wako Pure Chemical) was diluted to $10 \mathrm{ml}$ with distilled water to give a final glutaraldehyde concentration of $2.5 \%$ and this was added to the sieved fraction. The treated suspension was stored in a refrigerator for $1 \mathrm{~d}$.

Each $1 \mathrm{ml}$ aliquot of the treated and control suspensions was placed on a counting slide and examined under a regular light microscope to count the ciliate cysts. The ciliate cysts were categorized into 2 groups, 
i.e. Strombidium conicum and others, since the cysts of S. conicum have been well described by Kim (1995) in Onagawa Bay and are highly recognizable. The fluorescence capability of every ciliate cyst in the treated sample, regardless of state (intact or empty), was examined under blue-light excitation (450 to $480 \mathrm{~nm}$ ). Both intact and empty cysts were counted up to 50 cells. The fluorescent ratio of each group of cysts was calculated as the percentage of fluoresced cells to the total cells examined. An epifluorescence microscope (Olympus BX50) was equipped with a blue-light excitation filter held in a DM500 dichroic prism, with a barrier filter BA515 and a $100 \mathrm{~W}$ mercury lamp (U-MWB cube). The statistical difference in the cyst number between the treated and the control suspensions was determined using Student's $t$-test.

To assess the stability of the fluorescence capability of the treated cysts, the same treated sample was stored in a refrigerator for 1 mo and then examined again in the same way. An additional sediment sample, which had been obtained at a station in Uranouchi Bay $\left(32^{\circ} 26.19^{\prime} \mathrm{N}, 130^{\circ} 23.41^{\prime} \mathrm{E} ; 20 \mathrm{~m}\right.$ depth) open to the subtropical Pacific on March 2003, was also treated with glutaraldehyde. The sediment had been stored for about $1 \mathrm{yr}$ in a refrigerator without any pretreatment.

Recovery of the ciliate cysts by the density gradient centrifugation technique, which is commonly used in studies on dinoflagellates (Blanco 1986), was also carried out for comparison with the detection efficiency of the present method. The sediment sample obtained in Onagawa Bay in February 2004 was used. As the gradient medium, Ludox TM TM-50 colloidal silica (Aldrich) with a density of $1.40 \mathrm{~g} \mathrm{~cm}^{-3}$ was diluted with distilled water, after filtration through a paper filter to remove insoluble floccules (De Jonge 1979), into a series of $1.12,1.20,1.28,1.36$ and $1.40 \mathrm{~g} \mathrm{~cm}^{-3}$ in specific weight. Five $1 \mathrm{~g}$ aliquots of wet sediment were suspended in distilled water and sonicated for $30 \mathrm{~s}$. Their 20 to $100 \mu \mathrm{m}$ fractions were resuspended individually in ca. $20 \mathrm{ml}$ of distilled water and transferred to $50 \mathrm{ml}$ centrifuge tubes containing $20 \mathrm{ml}$ of each solution of the series of Ludox TM solutions. The tubes were centrifuged at $700 \times g$ for $15 \mathrm{~min}$. Detrital material between the layer of distilled water and the Ludox TM solution and on the bottom was withdrawn separately with a pipette onto a $20 \mu \mathrm{m}$ mesh filter and washed with distilled water. Detrital material retained on the filter was transferred into a vessel to which $1 \mathrm{ml}$ of glutaraldehyde was added and then made up to $10 \mathrm{ml}$ with distilled water. Recovered intact cysts of Strombidium conicum were counted under an epifluorescence microscope. As a control, the intact cysts in the 20 to $100 \mu \mathrm{m}$ fraction of $1 \mathrm{~g}$ of sediment treated with glutaraldehyde were counted without density gradient centrifugation.
In this investigation, only natural cyst assemblages were examined because no culture method to obtain a sufficient number of cysts of a single species in the laboratory is available. The ciliate cysts $>20 \mu \mathrm{m}$ in width were counted in the 20 to $100 \mu \mathrm{m}$ fraction in this investigation. This size range was reasonable since the loss to $<20$ and $>100 \mu \mathrm{m}$ fractions was only $3.8 \%$ of total cysts. Cyst species were identified by referring to Reid \& John $(1978,1983)$, Kim (1995) and Kim et al. (2002). Tintinnids could only be identified to genus due to breakage of the loricae, which are the key to species identification. All the examinations were replicated 5 times.

\section{RESULTS AND DISCUSSION}

\section{Fluorescence capability of ciliate cysts}

Fig. 1c,d shows microphotographs taken under regular lighting and epifluorescence lighting of a cyst of Strombidium conicum after glutaraldehyde treatment. The fluorescence of the cyst wall was always clear and yellowish-green under blue-light excitation and that of the papula or the plug of the extruding hole of an intact cyst was characteristically strong. This strong fluorescence made the intact cysts clearly visible even among detrital material in both sediments from Onagawa and Uranouchi bays (100\%; Table 1). Their fluorescence capability was fairly stable; the intact cysts were still brightly fluorescent 1 mo after glutaraldehyde treatment. Furthermore, the fluorescence capability was unchanged for the intact cysts in the sediment from Uranouchi Bay that had been stored for $1 \mathrm{yr}$ in a refrigerator, though their abundance decreased by ca. $20 \%$. On the other hand, weak fluorescence of empty cysts due to the absence of a papula, which had been lost during the excystment, makes the empty cysts indistinct, especially among detrital material (Fig. 1o,p). Only a portion of the empty cysts fluoresced poorly for $S$. conicum and other ciliates, i.e. 31.6 and $35.6 \%$, respectively. The rest of the empty cysts were not fluorescent. Therefore, glutaraldehyde treatment is useful for detecting and counting intact cysts in sediment suspensions.

It has previously been reported that many organisms and tissues fixed with fixatives such as formaldehyde and glutaraldehyde form covalent cross-links and become fluorescent (Weber et al. 1978, Epstein 1995, Haraguchi \& Yokota 2002, Johnson et al. 2003). However, fluorescence of ciliate cysts after formaldehyde fixation was weak or they were totally non-fluorescent (data not shown). Within our samples, cysts of dinoflagellates, resting spores of diatoms, resting eggs of zooplankters and pollen of terrestrial plants were 

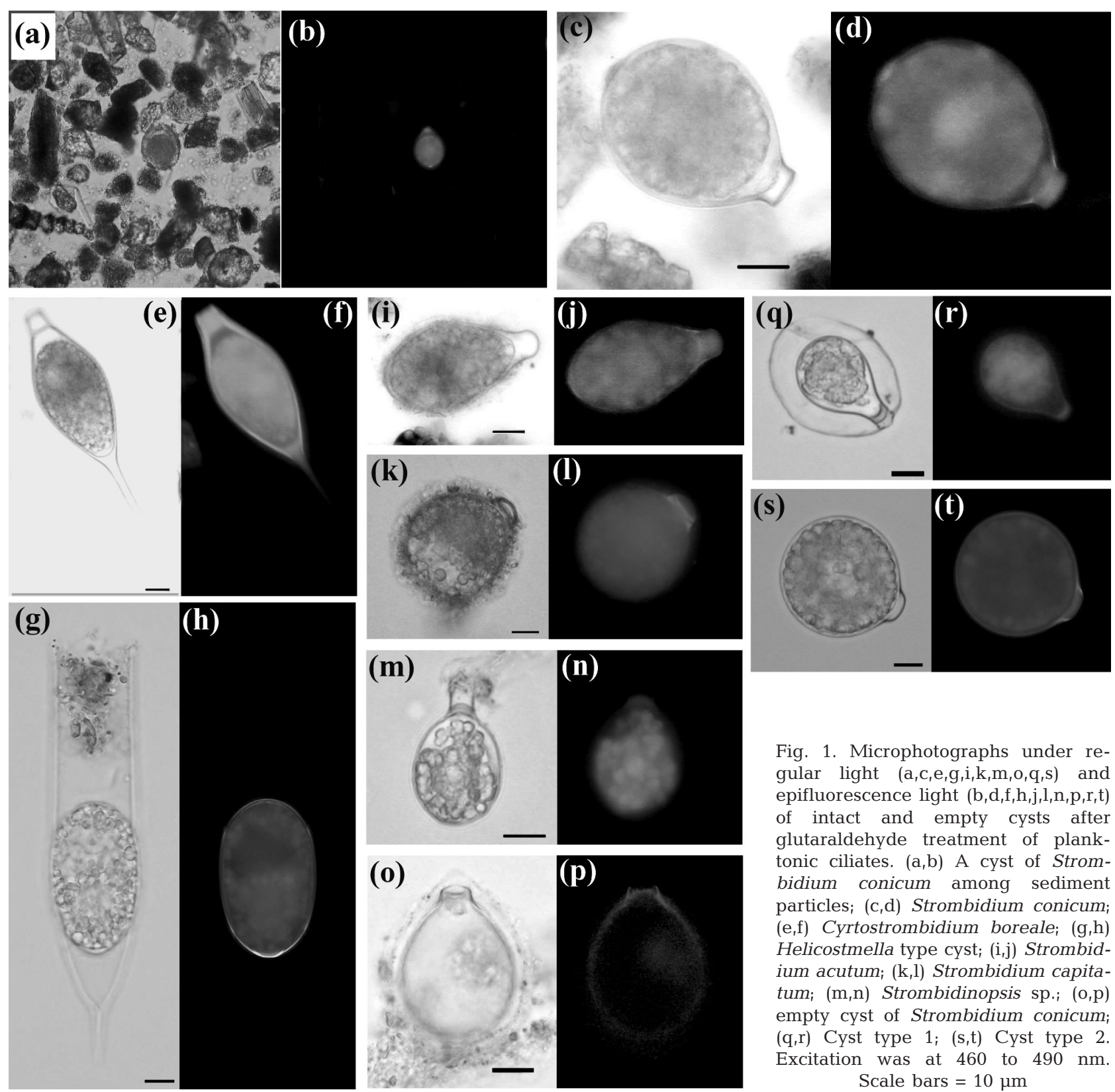

Fig. 1. Microphotographs under regular light $(\mathrm{a}, \mathrm{c}, \mathrm{e}, \mathrm{g}, \mathrm{i}, \mathrm{k}, \mathrm{m}, \mathrm{o}, \mathrm{q}, \mathrm{s})$ and epifluorescence light $(b, d, f, h, j, l, n, p, r, t)$ of intact and empty cysts after glutaraldehyde treatment of planktonic ciliates. $(\mathrm{a}, \mathrm{b})$ A cyst of Strom-

(o)

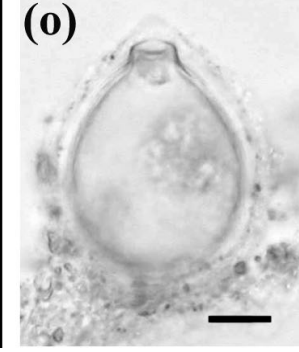

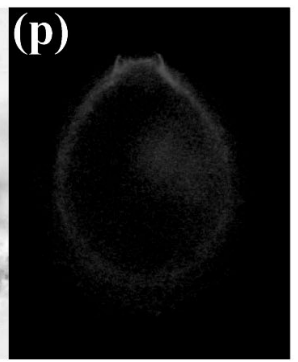

bidium conicum among sediment particles; (c,d) Strombidium conicum; $(\mathrm{e}, \mathrm{f})$ Cyrtostrombidium boreale; $(\mathrm{g}, \mathrm{h})$ Helicostmella type cyst; $(\mathrm{i}, \mathrm{j})$ Strombidium acutum; $(\mathrm{k}, 1)$ Strombidium capitatum; $(\mathrm{m}, \mathrm{n})$ Strombidinopsis sp.; $(\mathrm{o}, \mathrm{p})$ empty cyst of Strombidium conicum; $(\mathrm{q}, \mathrm{r})$ Cyst type $1 ;(\mathrm{s}, \mathrm{t})$ Cyst type 2. Excitation was at 460 to $490 \mathrm{~nm}$. Scale bars $=10 \mu \mathrm{m}$

Table 1. Ratios(\%) of fluorescent cysts to total intact and empty cysts for Strombidium conicum and other ciliates determined $1 \mathrm{~d}$ and 1 mo after glutaraldehyde treatment for Onagawa Bay sediment and the ratio for Uranouchi Bay sediment stored for 1 yr in a refrigerator. Number of tested cysts was 50 and every test was done in 5 replicates

\begin{tabular}{|lllccc|}
\hline & & & Strombidium conicum & Other ciliates & Total cysts \\
\hline Onagawa Bay & 1 d after glutaralde- & Intact cysts & $100 \pm 0$ & $100 \pm 0$ & - \\
& hyde treatment & Empty cysts & $31.6 \pm 4.6$ & $35.6 \pm 4.4$ & - \\
& $\begin{array}{l}1 \text { mo after glutaralde- } \\
\text { hyde treatment }\end{array}$ & Intact cysts & $100 \pm 0$ & & - \\
Uranouchi Bay & 1 yr after storage without & Intact cysts & - & - & $100 \pm 0$ \\
& glutaraldehyde treatment & & & & \\
\hline
\end{tabular}



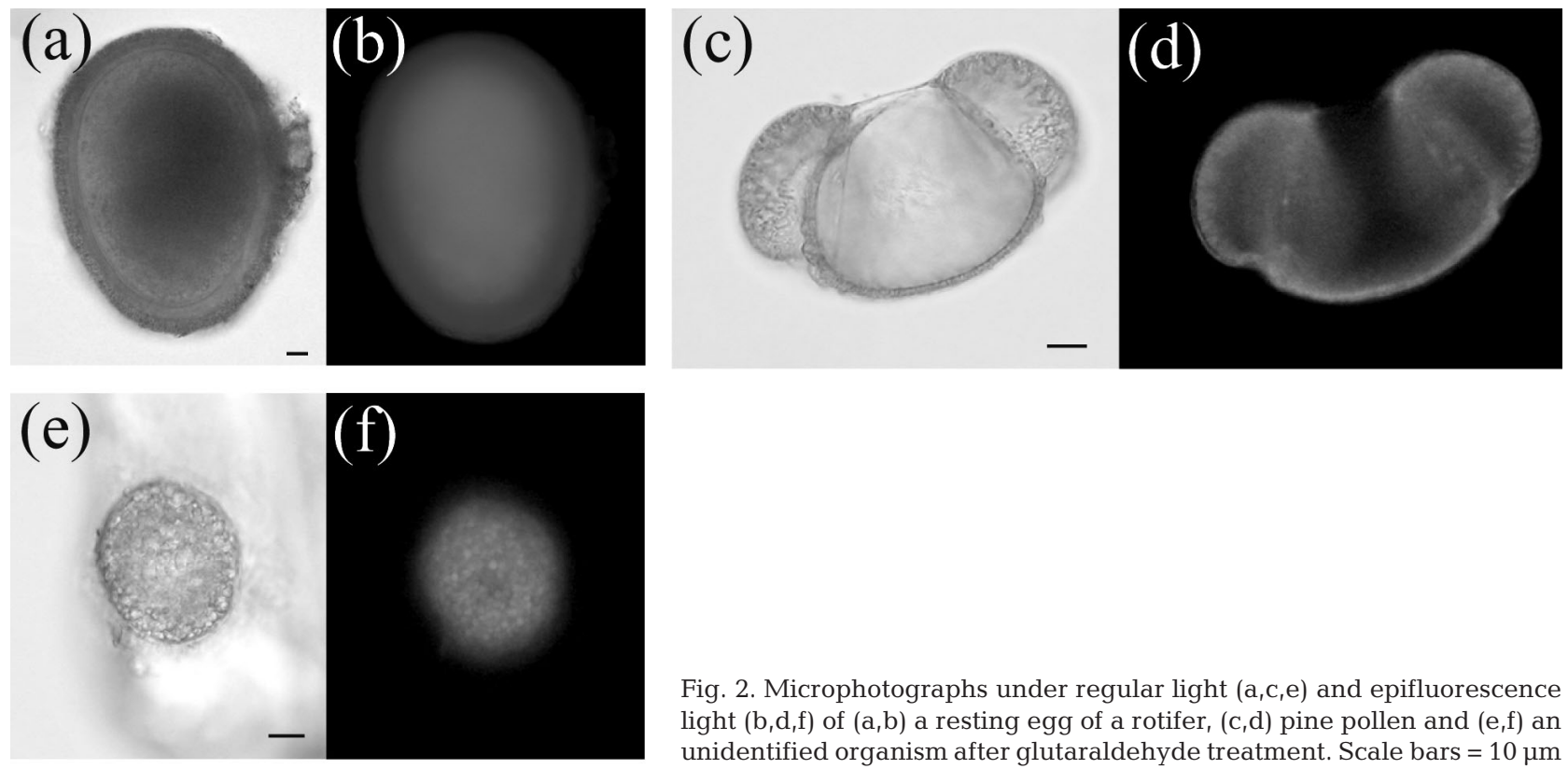

Fig. 2. Microphotographs under regular light $(\mathrm{a}, \mathrm{c}, \mathrm{e})$ and epifluorescence light $(b, d, f)$ of $(a, b)$ a resting egg of a rotifer, $(c, d)$ pine pollen and $(e, f)$ an unidentified organism after glutaraldehyde treatment. Scale bars $=10 \mu \mathrm{m}$

also found. After glutaraldehyde treatment, some of them became fluorescent, such as pine pollen, resting eggs of zooplankters (probably rotifers) and other unidentified organisms (Fig. 2). However, cysts of dinoflagellates, resting spores of diatoms and resting eggs of copepods were very poorly fluorescent or not fluorescent at all. Among the fluorescent organisms, the ciliate cysts were clearly distinguishable due to their characteristically strong fluorescence, particularly of the papula (Fig. 1a,b).
Among the cyst assemblage in Onagawa Bay, Strombidium conicum was the most dominant with 59.6 cysts $\mathrm{g}^{-1}$ wet sediment, followed by Strombidium acutum with 35.0 cysts $\mathrm{g}^{-1}$ wet sediment and Helicostomella spp. with 20.6 cysts $\mathrm{g}^{-1}$ wet sediment (Fig. 3). S. conicum has been reported to be the most dominant, with S. acutum and Helicostomella spp. as the secondary constituents, among planktonic ciliates in Onagawa Bay (Kim \& Taniguchi 1997). In contrast, in Uranouchi Bay abundance of the cysts of these species was low

\section{Enumeration of cysts in natural sediments at different localities}

In natural sediments collected from Onagawa Bay, Strombidium conicum cysts were the most abundant among the cyst assemblage, in both the glutaraldehyde treatment and the control (Fig. 3). However, the observed abundance was significantly higher in the glutaraldehyde treatment than in the control. The same was the case for Strombidium acutum, Strombidium capitatum and Helicostomella spp. It is noteworthy that the counts for the glutaraldehyde treatment were always higher than the control even for the spiniferous cysts of $S$. acutum and $S$. capitatum covered with detrital materials, while no difference was detected for species of lower abundance (Fig. 1i-l).

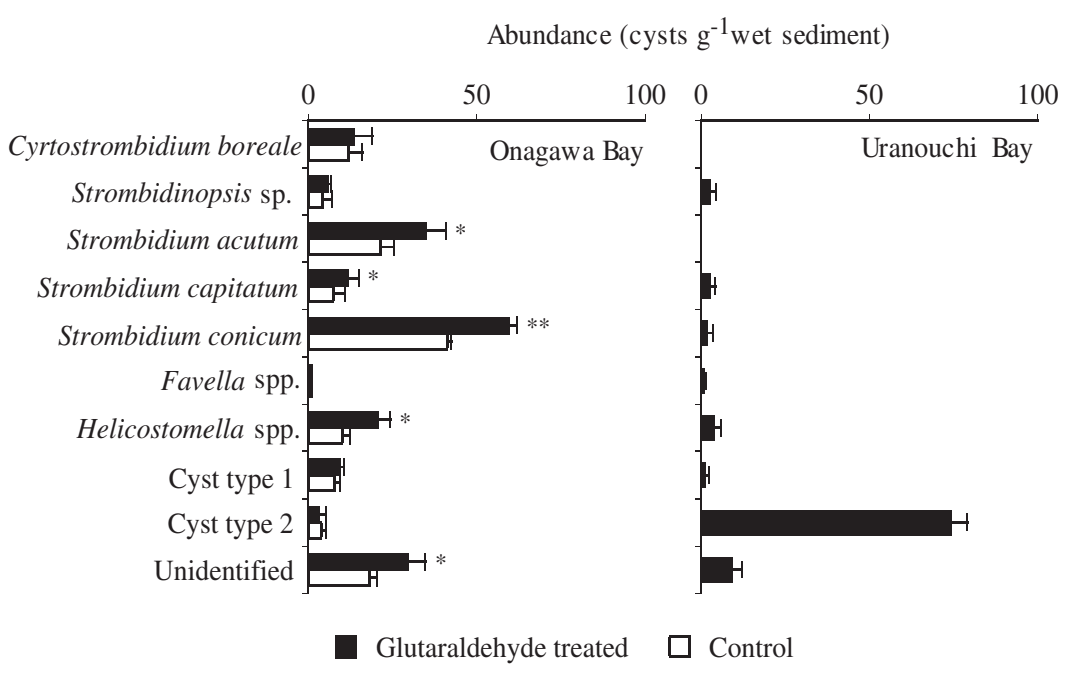

Fig. 3. Abundance of ciliate cysts (cysts $\mathrm{g}^{-1}$ wet sediment) counted for control and glutaraldehyde treated sediments collected in Onagawa Bay and for treated sediment in Uranouchi Bay. Unidentified: cysts with a papula, but their taxonomic affinity was not clear. Error bars indicate $\pm \mathrm{SD}$, $\mathrm{n}=5 . * \mathrm{p}<0.05, * * \mathrm{p}<0.01$ (Student's $t$-test) 


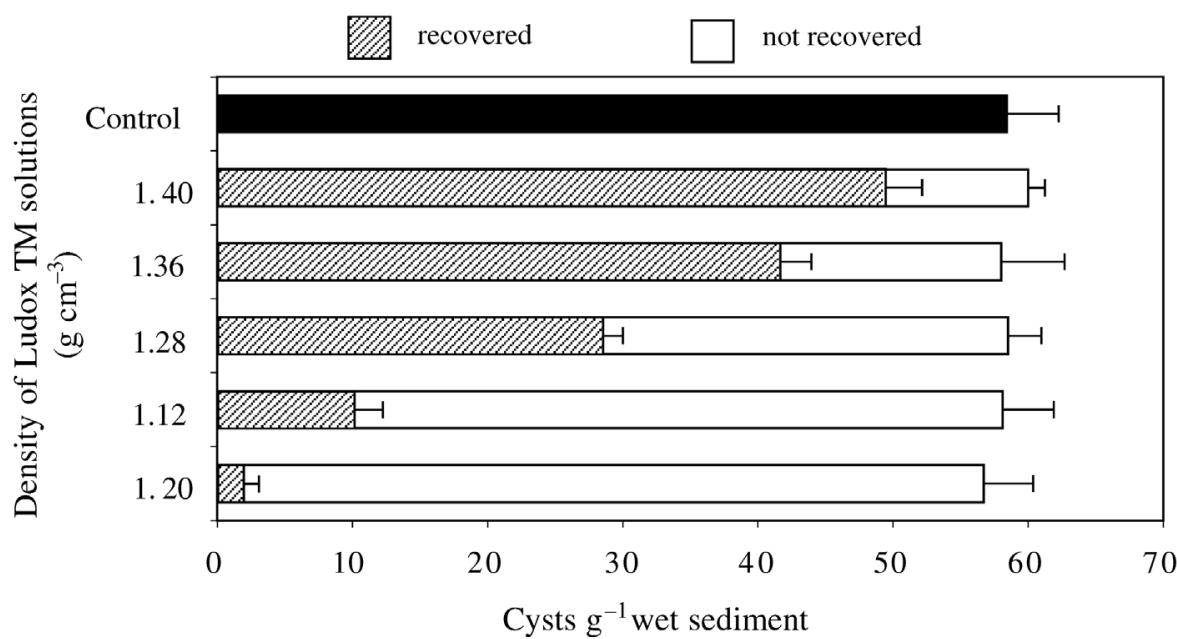

Fig. 4. Strombidium conicum. Number of recovered and not recovered intact cysts (cysts $\mathrm{g}^{-1}$ wet sediment) from the sediment in Onagawa Bay by the density gradient centrifugation technique using Ludox TM solutions. The cysts recovered by each solution were counted by the glutaraldehyde treatment method. Error bars indicate $\pm \mathrm{SD}, \mathrm{n}=5$

( 0 to 3.6 cysts $\mathrm{g}^{-1}$ wet sediment for the 3 species). However, the Cyst type 2 (a species independent of those previously mentioned and of unclear taxonomic affinity, Fig. 1s,t) was most abundant (74.0 cysts $\mathrm{g}^{-1}$ wet sediment) (Fig. 3), though total abundance was at a similar level as in Onagawa Bay. These results suggest that the species composition of the planktonic ciliate community is essentially different between the 2 bays.

\section{Comparison of glutaraldehyde treatment with the density gradient centrifugation method}

The recovered cysts of Strombidium conicum gradually increased as the density of the Ludox TM solutions increased, being lowest ( 1.9 cysts $\mathrm{g}^{-1}$ wet sediment) at the lowest density of $1.12 \mathrm{~g} \mathrm{~cm}^{-3}$ or $3.3 \%$ of the cysts detected by glutaraldehyde treatment (58.4 cysts $\mathrm{g}^{-1}$ wet sediment) in the control sediment (Fig. 4). On the other hand, at the highest density of $1.40 \mathrm{~g} \mathrm{~cm}^{-3}$ the recovered cysts were 49.4 cysts $\mathrm{g}^{-1}$ wet sediment or $85 \%$ of total cysts, which was similar to the value for dinoflagellate cysts in a previous study (Bolch 1997). However, 8.8 cysts $\mathrm{g}^{-1}$ wet sediment were lost to the bottom because of excess weight due to attached detrital material (cf. Yamaguchi et al. 1995). Therefore, the present method is more practical for enumerating ciliate cysts in sediments than the density gradient centrifugation method and the panning technique (Matsuoka et al. 1989) based on the same principle. However, it must be noted that density gradient centrifugation is advantageous in collecting live cysts to be used for culture experiments when non-toxic gradient media such as Nalco 1060 (Schwinghamer et al. 1991) and sodium polytugstate (Bolch 1997) are employed.

Although the most probable number (MPN) method (cf. Imai et al. 1984) is also commonly employed in enumeration of resting stage cells in sediments, it is only adaptable for viable (ready-to-germinate) cells and requires a priori information about the culture conditions suitable for their excystment, such as optimal temperature and irradiance.

\section{CONCLUSION}

To understand the ecology of planktonic ciliates, a quantitative investigation of their cyst populations in the sediment and their vegetative populations in the water column is indispensable. Although the present method is not adaptable to empty cysts, which emit weak or no fluorescence (Table 1), it is valid for intact cysts and can be employed as a practical method in future routine analysis of cyst populations in natural sediments.

Acknowledgements. We wish to thank Professor T. R. Parsons and Dr. T. Ota for their discussion about the present methods and results. We are grateful to Professor P. J. Harrison for his kind reading of and constructive comments on our manuscript.

\section{LITERATURE CITED}

Blanco J (1986) Separacion de quistes de dinoflagelados en gradiente de densidad. Bol Inst Esp Oceanogr 3:81-84

Bolch CJS (1997) The use of sodium polytugstate for the separation and concentration of living dinoflagellate cysts from marine sediments. Phycologia 36:472-478

De Jonge VN (1979) Quantitative separation of benthic diatoms from sediments using density gradient centrifugation in the colloidal silica Ludox-TM. Mar Biol 51:267-278

Epstein SS (1995) Simultaneous enumeration of protozoa and micrometazoa from marine sandy sediments. Aquat Microb Ecol 9:219-227

Haraguchi CM, Yokota S (2002) Immunofluorescence technique for 100-nm-thick semithin sections of Eponembedded tissues. Histochem Cell Biol 117:81-85

Imai I, Itoh K, Anraku M (1984) Extinction dilution method for enumeration of dormant cells of red tide organisms in marine sediments. Bull Plankton Soc Jpn 31:123-124

Johnson MD, Rome M, Stoecker DK (2003) Microzooplankton grazing on Prorocentrum minimum and Karlodinium micrum in Chesapeake Bay. Limnol Oceanogr 48:238-248

Kamiyama T (1996) Determination of the abundance of viable tintinnid cysts in marine sediments in Hiroshima Bay, the Seto Inland Sea of Japan, using a modified MPN method. J Plankton Res 18:1253-1259 
Kamiyama T, Anzai Y (1990) Excystment of tintinnid ciliates from marine sediment. Bull Plankton Soc Jpn 36:138-139

Kim YO (1995) Life cycle strategies of choreorich ciliate plankton in Onagawa Bay. $\mathrm{PhD}$ thesis, Tohoku University, Sendai

Kim YO, Taniguchi A (1995) Excystment of the oligotrich ciliate Strombidium conicum. Aquat Microb Ecol 9:149-156

Kim YO, Taniguchi A (1997) Seasonal variation of excystment pattern of the planktonic oligotrich ciliate Strombidium conicum. Mar Biol 128:207-212

Kim YO, Suzuki T, Taniguchi A (2002) A new species in the Genus Cyrtostrombidium (Cliliophora, Oligotrichia, Oligotrichida): its morphology, seasonal cycle and resting stage. J Eukaryot Microbiol 49:338-343

Matsuoka K, Fukuyo Y, Anderson DM (1989) Method for modern dinoflagellate cyst studies. In: Okaichi T, Anderson DM, Nemoto T (eds) Red tides; biology, environmental science, and toxicology. Elsevier, New York, p 461-479

Müller H (1996) Encystment of the fresh water ciliate Pelagostrombidium fallax (Ciliophora, Oligotrichida) in laboratory culture. Aquat Microb Ecol 11:289-295

Müller H, Wünsch C (1999) Seasonal dynamics of cyst formation of pelagic strombidiid ciliates in a deep prealpine lake. Aquat Microb Ecol 17:37-47

Müller H, Stadler P, Welsse T (2002) Seasonal dynamics of

Editorial responsibility: John Dolan,

Villefranche-sur-Mer, France cyst formation of strombidiid ciliates in alpine Lake Mondsee, Austria. Aquat Microb Ecol 20:181-188

Paranjape M (1980) Occurrence and significance of resting cysts in a hyaline tintinnid, Helicostomella subulata (Ehre) Jörgensen. J Exp Mar Biol Ecol 48:23-33

Reid PC (1987) Mass excystment of a planktonic oligotrich ciliate. Mar Biol 95:221-230

Reid PC, John AW (1978) Tintinnid cysts. J Mar Biol Assoc UK 58:551-557

Reid PC, John AW (1983) Resting cysts in the ciliate class Polymenophores: phylogenetic implications. J Protozool 30:710-713

Schwinghamer P, Anderson DM, Kulis DM (1991) Separation and concentration of living dinoflagellate resting cysts from marine sediments via density-gradient centrifugation. Limnol Oceanogr 36:588-592

Weber K, Rathke PC, Osborn M (1978) Cytoplasmic microtubular images in glutaraldehyde-fixed tissue culture cells by electron microscopy and by immunofluorescence microscopy. Proc Natl Acad Sci USA 75:1820-1824

Yamaguchi M, Itakura S, Imai I, Ishida Y (1995) A rapid and precise technique for enumeration of resting cysts of Alexandrium spp. (Dinophyceae) in natural sediments. Phycologia 34:207-214

Submitted: November 1, 2003; Accepted: August 23, 2004 Proofs received from author(s): November 10, 2004 